\title{
TOWARDS RESPONSIBLE GEOGRAPHIES OF MEMORY: COMPLEXITIES OF PLACE AND THE ETHICS OF REMEMBERING
}

\author{
Karen E. Till and Anna-Kaisa Kuusisto-Arponen \\ With 6 photos \\ Received 18 May $2014 \cdot$ Accepted 02 July 2015
}

\begin{abstract}
Summary: Debates about the meanings of place often emerge when unsettled pasts resurface unexpectedly in ways that dislocate present-day land-uses. Such was the case for the IGU 2011 Regional Meeting in Chile, which was held in Santiago's Military Academy. When considering the geographical scholarship about place and memory, the debates resulting from the conference should not be surprising. Geographers have long examined the controversial processes of social memory and forgetting at places marked by state-perpetrated violence and have noted the unpredictability of group memory due to the translocal nature of how places are connected to peoples and pasts through socio-political networks, cultural and economic connections, and personal and shared emotional geographies. To understand the complexities of ethical relationships we have with places marked by violence, we look to another example, the Memorial and Museum Camp Westerbork in the Netherlands. The past is never 'set in stone' or stable in present-day landscapes. Just as the narratives associated with remembering and forgetting the past may change through time, so too do the spatial contexts of memory. When space-times shift unexpectedly, new social discussions about the significance of the past in the present may emerge. With both examples in mind, we conclude by making a case for the creation of "responsible geographies of memory". We argue that it is our professional responsibility as geographers and our obligation as global citizens to: 1) acknowledge that landscapes often function as places of critical testimony for survivors; 2) problematize singular claims to the authenticity of place made through universal narratives and seemingly stable material landscapes; 3 ) create safe spaces of listening, wherein stories about place can be articulated and acknowledged by various stakeholders, while recognizing the moral complexities in representing violence through textual, visual and embodied means; and 4) recognize the progressive potential of places as cosmopolitan spaces of encounter and learning. By treating places marked by difficult pasts as cosmopolitan, hosts and visitors are invited to engage critically with the unfolding processes of memory politics, and adopt respectful approaches toward justice that includes caring for places and peoples in the past and present.
\end{abstract}

Zusammenfassung: Debatten über die Bedeutung von Orten der Erinnerung entstehen oftmals, wenn eine nicht aufgearbeitete Vergangenheit die gegenwärtige Nutzung dieser Orte in unerwarteter Weise in Frage stellt. Genau dies war der Fall, als im Jahr 2001 das IGU Regional Meeting in Chile in Santiagos Militärakademie ausgerichtet wurde. Ein Blick in die einschlägige geographische Literatur über Erinnerungsorte lässt die aus dieser Konferenz sich ergebende Debatte kaum überraschend erscheinen. Die kontroversen Prozesse kollektiven Gedenkens und Vergessens an Orten, die durch staatlich verübte Gewaltverbrechen gekennzeichnet sind, gelten seit langem als Gegenstand geographischer Forschung. Die Erkenntnisse belegen, dass kollektives Gedenken angesichts des translokalen Charakters, wie Orte mit Menschen und ihrer Vergangenheiten durch sozio-politische Netzwerke, kulturell und ökonomische Verbindungen sowie persönliche und geteilte Geographien der Emotion verknüpft sind, letztlich unvorhersehbar bleibt. Um die Komplexität unserer ethischen Beziehungen zu von Gewalt geprägten Orten zu verstehen, betrachten wir ein weiteres Beispiel - die „Gedenkstätte und Museum Lager Westerbork“ in den Niederlanden. Vergangenheit ist nie "in Stein gemeißelt" oder gleichbleibend in der gegenwärtigen Landschaft. Ebenso wie sich die mit Gedenken und Vergessen verbundenen Geschichten im Laufe der Zeit verändern können, gilt dies auch für räumliche Kontexte der Erinnerung. Kommt es zu unerwarteten Verschiebungen dieses raum-zeitlichen Gefüges, können daraus neue soziale Diskussionen über die Bedeutung der Vergangenheit für die Gegenwart erwachsen. Auf der Grundlage beider Fallbeispiele plädieren wir in der Schlussfolgerung für die Entwicklung ,,verantwortungsbewusster Geographien der Erinnerung“. Wir sind der Auffassung, dass es sowohl unserer professionellen Verantwortung als Geographen, als auch unserer Pflicht als Weltbürger entspricht: 1) anzuerkennen, dass Landschaften oftmals bedeutsame Zeugnisse für Überlebende darstellen; 2) einseitige Ansprüche auf Authentizität von Orten zu hinterfragen, die sich aus universalen Narrativen und vermeintlich beständigen materiellen Landschaften ergeben; 3) sichere Räume des Zuhörens zu schaffen, in denen unterschiedliche Interessengruppen ihre jeweiligen Erzählungen artikulieren und anerkennen sowie die moralische Komplexitäten der Gewalt textlich, visuell und verkörpert vermittelt werden können, und 4) das zunehmende Potential von Orten der Erinnerung als kosmopolitische Räume der Begegnung und des Lernens zu erkennen. Eine kosmopolitische Sicht auf historisch belastete Orte lädt Veranstalter und Besucher dazu ein, sich mit den Prozessen von Erinnerungspolitiken kritisch auseinanderzusetzen und eine respektvolle Haltung gegenüber einer solchen Gerechtigkeit einzunehmen, die (Für-)Sorge für Erinnerungsorte wie auch Menschen in Vergangenheit und Gegenwart einschließt.

Keywords: Memory and place, cosmopolitan place, ethics of remembering, violent pasts, authenticity, Westerbork Transit Camp 


\section{Introduction}

"It seems a missed opportunity. Clearly, almost any conference venue has some ghosts in the closet, so one might just give up and always stay at home. Yet this was a particularly egregious ghost as well as a superb chance for some critical engagements. To admit errors of the past, even if one was not directly involved, requires a lot of courage" (KULL 2011).

“...Why boycott a well organized conference on geography based on [the] past history of the building....what does geography have to do with the coup in 73 ? Were you there to discuss politics or geography?" (Velasco 2013).

The 2011 Regional Meeting of the International Geographical Union (IGU) in Santiago, Chile resulted in a controversy amongst its membership about understandings of the responsibility of the IGU to pay attention to the memory politics of a particular place, as well as the history of our discipline (Hirt and Palomino-Schalsa 2011). ${ }^{1)}$ For many, the well-organized conference was considered a success, attracting over 850 participants from over 60 countries with a large representation of Latin American Geographers. Numerous student travel grants awarded by the Association of American Geographers (AAG) also enabled younger scholars to participate (SANGER 2012). However, because the local host, the Instituto Geográfico Militar (IGM), chose to hold the conference in the Escuela Militar, or Military Academy, an international petition was circulated to change the venue. The petition noted that the Escuela Militar was a known former site of torture; it was where planning for human rights abuses under the former Pinochet dictatorship (1973-1990) took place. Moreover, Pinochet himself taught at the military academy. Finally, the IGM itself was appointed by Pinochet as the IGU's Chilean Geography representative in 1979 and has remained the official national organization representing the discipline to the IGU (Hirt and Palomino-Schalsa 2011).

1) The IGU is an international scholarly network that rotates the venues of its conferences in an attempt to represent its broad membership. Since the 1970s, it included member states undergoing democratization and encouraged meetings to be hosted in Global South and Asian member states. As a general rule, the IGU seeks to promote a policy of non-interference: once the decision is made about the next conference host, that member state makes decisions about all conference details. The IGU selected Chile as the venue of the Regional Meeting seven years before the conference took place.
In response to these allegations, the IGM noted that the academy had been built long before the Pinochet regime and has since also been used for other purposes, such as academic conferences, for the past twenty years. The international discussions resulted in some geographers choosing to boycott the meeting, whereas others considered such a boycott as "ridiculous" (Velasco 2013). At the same time, some who did attend the meeting were surprised that there was no discussion about the "history, site, memory, and associations of the place", especially following student protest actions that included the distribution of flyers detailing the conference venue's history in relation to Geography and a silent march with banners; these actions were ignored by plenary speakers and military security, the latter of which escorted the protestors out of the conference venue (Kull 2011).

Acknowledging geographers' contributions to studies about the politics of memory, the IGU executive committee organized a special panel at their 2012 Congress in Cologne to discuss the larger theoretical as well as practical questions raised by the IGU Santiago controversies. Nonetheless, during the discussion period, questions were again raised about whether an international academic conference is responsible for paying attention to local political controversies, and if so, if an international professional organization has the right to intervene in the decisions of local hosts. ${ }^{2)}$ This paper emerges from that discussion as a means of revising the larger points raised and engaging in recent debates about geography, trauma, and the ethics of research and professional responsibility. We argue that professional scholarly organizations need to be mindful and respectful of the geographies of memory that surround meeting locations and institutional settings around the globe.

In this article we develop ENTRIKIN's (1999) concept of cosmopolitan place as a contribution both to ongoing discussions about the profession of Geography (Alderman and Campbell 2008) and to geographical research about place and memory. The meanings and "ghosts of place" (BELL 1997; CERTEAu et al. 1998) often challenge taken-forgranted assumptions about how shared understandings of space and time "should" work. As

\footnotetext{
2) Speakers were invited to discuss NorA's (1984) concept lieux de memoire. None of the invited speakers were experts about Chilean memory politics. This paper extends some of the early ideas introduced at that panel by TiLL and draws upon works by ENTRIKIN, who was also a speaker.
} 
cultural, historical and political geographers have argued, difficult pasts often emerge when unsettled pasts unexpectedly resurface in ways that dislocate the present-day functions of places (JonKer and Till 2009; Korjonen-Kuusipuro and KuusistoArponen 2012; Pile 2005). If professional organizations ignore the spatial legacies of the trauma and discrimination, their meetings become part of the symbolic and material process of endorsing a forgetful scripting of painful histories and place-based identities.

As we argue in this article, when proposals about the (re)use of buildings, locations, place-names, and institutions once associated with violence become controversial, as both citizens of the world and professionals of international, national and local communities, we should create spaces to listen to and understand why different stakeholders may wish to raise questions or stories about traumatic pasts at a particular place and moment in time, particularly if our presence has triggered those discussions. Our ethical responsibility to attend to places marked by violent pasts also means that professional organizations cannot defer to the scale of the international as more important than or off-limits to local concerns, a point raised by NICK ENTRIKIN at the IGC in Cologne in 2012. In the next section, we briefly review "the inextricable link between memory and place" and "the unpredictability of group memory" (Hoelscher and Alderman 2004, 348), calling attention to the ways places are both universal and relational, as well as particular and contingent (cf. Sundholm 2011). Looking to the Memorial and Museum Camp Westerbork in the Netherlands as a case study, we demonstrate how social claims to the past may "limit" the space-times of place instrumentally to promote singular narratives about victims and perpetrators. Even at important international educational centers about the history of World War II and the Holocaust, forms of remembering and forgetting the past may change due to the unexpected ways that stories, land uses, material landscapes and attachments to place unfold. We conclude by making a case for more "responsible geographies of memory" by problematizing authenticity, respecting multiple stories of various stakeholders, and introducing the concept of cosmopolitan place. Such a place-based ethical approach to heritage site development would be open to spatial, social and temporal complexities and contradictions, and might allow for understanding different forms of belonging yet be respectful of the ongoing legacies of violence.

\section{Geographies of memory}

In the interdisciplinary field of memory studies, the two influential texts that launched studies about geographies of memory were Pierre Nora's (1984) influential Les Lieux de Mémoire and Maurice Halbiwachs' (1992) re-released La Mémoire Collective, first published posthumously in 1950. NorA's early work explored the emergence of modern 'sites' (lieux) of memory as tied to rise of history and the European nation-state. His research team later coauthored a multi-volumed inventory documenting the range of French nationalist sites, from nationalist abstract concepts to stamps to people to ceremonies to archives (cf. NOrA and Kritzman 1996), an approach that has inspired other similar national studies of the history of memory, including Deutsche Erinnerungsorte (FRANÇOIS and SCHUlZE 2001, 2005). HalbWACHS, as influenced by Henri Bergson and Emile Durkheim, argued that memory, in particular recollection, was always constructed and located in the social environments of the present, such as through group anniversaries, celebrations, historical collections, and through other narratives, landscapes and performances. His research explored "collective frameworks of memory" as functioning instrumentally for groups and continuously changing according to the needs of the present. Group narratives and embodied performances were most powerful when anchored to "landmarks", wherein the superimposition of symbolic meaning onto a physical reality legitimized a group's memorial "topography" (TILL 1999; KuUsisto 2001).

There are now several excellent overviews of geographers' contributions to understanding the fundamental relationships between place, landscape and memory (Alderman and Inwood 2013; Dwyer and Alderman 2008; Hoelscher and Alderman 2004; Kuusisto-Arponen 2009; McDowell 2009; Till 2005). Here, we briefly call attention to two broad overlapping strands of geographical scholarship. First, geographers have examined the contested nature of memory by tracing the ways that groups and individuals struggle with one another to gain authority to represent their version of the past in public spaces, including materially in the built environment, virtually through the media, and structurally through governmentality (laws, claiming moral territory, classifying spaces of belonging). A number of empirically rich case studies now detail the memorial processes that go into the making of commemorative landscapes and heritage sites, official and vernacular public displays, street 
naming practices and tourism (ALDERMAN 2002; Azarayu 1997; DeLyser 2005; Dwyer 2006; Foote 1997; Forest and Johnson 2002; Harvey 1979; HeFFernan 1995; Hetherington 1997; Hoelscher 1998; JoHnson 1999; Withers 1996). In these works, geographers examine the ways that officials of the state sanctify prominent locations through statuary, memorials, museums, grand boulevards, public squares, ornate buildings, and public rituals, to communicate selective national and urban histories. This is not to say that the material and symbolic resonances of memorials, monumental public landscapes and sacred topographies indicate either a coherent set of political agendas or passive acceptance of these cultural messages about the past (AGNEW 1998; Atkinson and Cosgrove 1998; Forest et al. 2004). Unlike many memory studies scholars, geographers understand place-making as a process of constructing and helping us understand the world (Adams et al. 2001; Cresswell 2006), including embodied personal and social memory practices at multiple scales (KuUSISTO-ArPONEN 2009; 2014). In particular, geographers pay attention to the sociospatial processes associated with place and memory according to inter/textuality, arenas of contestation, and landscape representation and performativity (Dwyer and Alderman 2008; Till 2003).

A second strand of research highlights the translocal and transgenerational nature of memory, particularly in instances of personal and social trauma. Research highlights how personal and shared memory practices are at once embedded, yet move in and through a range of spaces, such as through spectral geographies, bodies in motion, emotional attachments, social movements and global networks (Bosco 2006; Hill 2013; KuUsisto-ArponeN 2011). Memory politics are never only 'located' in Cartesian space; as transcultural signifiers they are communicated across and through spaces and places, and travel through and with personal and shared emotions, memories, and affects (DERRIDA 1995; Nora and Kritzman 1996; KuUsisto-Arponen 2009; ERLL 2011). When site-specific symbols and practices of visualising the past are contextualized in new settings, their meanings and politics change. This is because places are constituted and created by translocal social relations (MASSEY 2005); the "layer upon layer of different sets of linkages, both local and to the wider world" (MAssey 1991, 29), contribute to the historical specificity of place and memory. A relational understanding of place means thinking about "articulated moments in networks of social relations", rather than static containers that "frame simple enclosures" (ibid). Within networks, we can analyze existing hegemonic ideas about how more abstract "types" of place (a city, home, nation-state, body, region, memorial, museum) are expected to function in a society, as well as the historically and geographically unique, albeit contingent, mixture of social relations that result in the distinctiveness of a given particular place. When discussing how both a type of place of memory or a particular place resonates within and beyond cultural and historical landscapes of violence, questions about what is remembered and why become critical. As TYNER et al. $(2014,911)$ argue the potential and actual memorialization of violence through the landscape is always a dynamic process that involves different abstractions of violence. Thus, when trying to understand how places are remembered as marked by violence, scholars must critically analyse how violence itself is represented (or not) through particular narratives, as well as the reasons why and how groups may use place and landscape to assert the authenticity of their respective scripts about the past.

Drawing upon the insights of these geographical strands of research, in the next section, we discuss a well-established, multi-layered and more 'remote' international Holocaust heritage memorial complex, the Westerbork Camp Memorial Museum in the Netherlands. Originally built as a refugee camp for European Jewish before the outbreak of World War II, Westerbork came to function as a Nazi transit camp, and in the postwar period as an internment camp, a military camp, and a refugee camp for those of the former Dutch empire. The terrain was used for other social functions as well. In 1971, memorials were established, and in 1983, as a result of a private initiative, a memorial museum center created to commemorate those who suffered and died during World War II. Even after Westerbork became a Holocaust memorial center, unanticipated changes to the material landscape of the historic terrain resulted in the resurfacing of memories and old controversies, and opened a gap for new commemorative strategies to be considered.

\section{Memorial Center Camp Westerbork: whose heritage?}

The Westerbork Memorial Museum is located in Hooghalen, three kilometers from the historic memorial camp. Funded by the Dutch government, it includes exhibitions, artefacts, recreations, still and moving film, drawings and paintings, educational 
seminars, historic memorial grounds, and archives. ${ }^{3)}$ When one visits a Holocaust or WWII memorial site, one brings a vivid imagination and a "postmemory" of previously viewed photographic images and historical films, as well as memories of visits to other memorials and museums (Hirsch 2012). Museum exhibitions and memorial landscapes about violent pasts at Holocaust sites combine emotive, embodied and authoritative approaches to provide visitors with an authentic and educational story about the historic site. While learning about the histories of World War II and the Holocaust is more viscerally effective and powerful through historic places of violence, we argue that more critical engagements with place and landscape at Westerbork may allow for more complex understandings of Dutch and European identities in the past and present. After a short overview of the many ways that Westerbork was used during and after the war, we explain why the musealization of a "global" narrative of the Holocaust remembrance is problematic at this particular place.

Westerbork was first built as a refugee camp in October 1939 through Jewish financial support, in response to the Dutch government closing their borders to Jewish refugees in 1938. By 1942, the Nazis took the camp over and changed its function to detain and deport Romani and European Jews to other concentration camps. Some European women and resistance fighters were also imprisoned in Westerbork. From 1942-44, 93 cargo trains departed, about one every Tuesday, leaving for Auschwitz-Birkenau, Sobibór, Bergen-Belsen and Theresienstadt; of the 107,000 detained or deported during this time only about $5 \%$ survived. The most well-known camp prisoner was Anne Frank and her family, who were on one of the last three trains leaving Westerbork.

After the war, it was used as an internment camp, or prison, for alleged and accused Nazi collaborators. Beginning in 1950, Dutch military troops and nationals who fled the former Dutch East

\footnotetext{
3) Unless otherwise cited, much of the factual information about Westerbork in the following paragraphs comes from the Westerbork Memorial Museum Center webpage: http://www. kampwesterbork.nl/en/index.html. A separate documentation center also offers books, documents, photographs, and videotapes for researchers (http://www.kampwesterbork.nl/ en/museum/archief-en-collectie/archives-and-collections/ index.html). The museum also houses the "Memorial Books of the 'Oorlogsgravenstichting' (War Graves Foundation)" that record the 140,000 names of "Dutchmen who were killed during World War II and who did not receive a proper burial" (http://www.kampwesterbork.nl/en/museum/herinneringscentrum/camp-westerbork-museum/index.html).
}

Indies (Indonesia) stayed there, and from 1951-71 Westerbork was renamed to Camp Schattenberg and used to house Moluccan refugees ${ }^{4}$; some new buildings were erected during this time. Due to the camp's rather remote location, the Westerbork Synthesis Radio Telescope (WSRT) station was erected in 1969-70. This multivocal and socio-materially diverse history of the heritage site is clearly a good example of translocal memory contestations and disputes.

\subsection{Selective voices from the past: The exhibition}

" 'Dear All,

Finally it has come. We are on the list. We had hoped that despite everything we could see each other again soon, but alas this won't happen for a while. We hope God will protect you. We must remain strong. A big kiss to everyone,

Moe'

This heart-breaking postcard, written by a camp inmate upon finding her name on the list for transportation, hangs near the entrance to the Memorial Centre Camp at the Westerbork Museum. The museum exhibits a collection of photos, objects, and audio interviews with survivors, as well as unique film footage of the camp. The names of the 102,000 victims are continually projected on a screen. Some of the objects, like school reports from the children in the camp's school, can be touched and picked up" (DOOLAN 2010).

What happens when Holocaust commemoration practices travel and provide the visitor with a universal set of expected landmarks and stories about the victims that they look for to satisfy their desire to see a "real" place of violence (cf. ChARLESWORTH 1994)? As this visitor's experience quoted above illustrates, the Westerbork museum provides a sense of what a transit camp was through reconstructions of the daily routines of the inmates, personalised stories about the victims, and references to other Holocaust places. These affective geographies are part of the Holocaust heritage experience and are invoked by exhibition designers and authors through: the use of oral histories to communicate empathetic stories from the perspective of those who lived through the pasts exhibited; embodied memorial practices, such as moving through exhibition spaces or through memorial landscapes, and interacting with/observ-

4) The Maluku Islands are an archipelago within Indonesia. 
ing artefacts (real or recreated); and distanced, authoritative historical narratives that communicate factual data within a larger comparative framework. The main exhibition at Westerbork "depicts Dutch war time under occupation, with special emphasis on the persecution of the Jews" (KAMPWESTERBORK). Visitors are also often reminded by memorial staff, exhibitions, and signage about the differences between the Nazi camps of violence and other types of camps to highlight how historic Westerbork, as a transit camp, was not a "bad" camp. This topographical mapping according to types of camps situates the visitor's perspective within a "global" perspective of Holocaust remembrance, and of victims and perpetrators (compare LeVY and SZNAider 2005).

The exhibition space includes suitcases, family photos, reproduced and some original postcards and letters, and other small personal items (Photo 1). The politics of artefact representation (Alderman and Campbell 2008, 345) are used to depict an embodied experience of what a transit camp might have looked like for the visitors. The visitor can move around this space in whatever direction s/he chooses and examine the objects on display; the amount of information is not overwhelming and there are spaces to take a break (and to sit down). Despite the seriousness of the topic, one does not often see visitors in the exhibition space crying or distressed; we believe that this may be related to the design of the exhibition space which is open overhead and does not have sections with dark lighting. Moreover, the content of the exhibition is appropriate for children, young people and adults, which means that no visual images of bodily violence or death are depicted. Toward the end of the main room, the visitor wanders "into" an "original" (reconstructed, partially built) barracks; after going "through a door" into this space

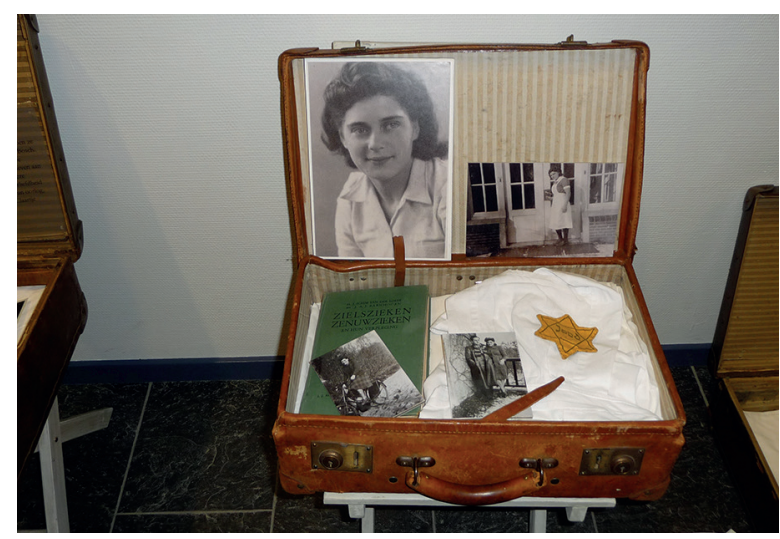

Photo 1: The stories of Jewish inmates in Westerbork Memorial Center (Photo: KuUsisto-ArPonen, January 2013) to see a sleeping bunk, clothes with Jewish stars and a suitcase with some personal items, one can wander back out into the open section or move to the end of the larger room to look at a large interactive map of Europe with electronic and factual information about the larger system of camps.

On the other side of the main exhibition space, a small section depicts the period in which the Moluccan refugees lived at the camp (1950-71). Unlike the interactive and open, well-lit main area, this part of the exhibition is darker, in a narrow, corridor-like exhibition space. Very little here is communicated in the empathetic or educational registers of the main exhibition. Instead, the main narrative voice is the Dutch media. One wall has green wooden remnants of a former barracks where Anne Frank and her sister Margo worked for four weeks in 1944 that burned down in nearby Veendam (about $40 \mathrm{~km}$ north of Hooghalen) in 2009; a television screen runs clips of media coverage of that event. ${ }^{5)}$ The presence of Anne Frank's iconic status in this part of the museum seems to downplay the Moluccan experience. While the emphasis of newspaper articles and media clips about the more recent fate of the barracks may trigger memories about this episode for adult visitors, the relic of Anne Frank's personal history, together with the relative lack of Moluccan personal stories and artefacts, mean that the latter are depicted as outsiders of Dutch society in the past and present. We did not find much information about their story depicted in the landscape in the outside memorial area. However, one guide mentioned that the visual feature of the window frames in the former barracks was intended to represent how these huts were transformed into the "homes" of Moluccans.

Although some memorial staff members indicated that an ongoing challenge of this heritage site was to provide an inclusive and respectful history about all the different populations at Camp Westerbork, including Jewish refugees (Dutch refugee camp, 1939-1942); European Jews, Romani and women (Nazi transit camp, 1942-1944); Nazi collaborators and several members of Dutch National Socialist Party (international postwar penalty camp,

5) In July 2009, the historic barracks, which was reused as an agricultural warehouse after 1957, burned down. The Bergen Belsen Concentration Camp Memorial Museum had planned to take the barracks later that year for a new Anne Frank museum. After the fire, the Westerbork museum created a wall in the exhibition with the salvaged barrack remnants, which was open to the public in December 2009. 
1945-1948); troops discharged from the Dutch East Indies (Dutch military camp, 1950-1951); and South Moluccan refugees (Dutch Camp Schattenberg, 1951-71), these 'other' social histories have very little space - narrative, artefact or visual presence - in the museum's permanent exhibition. Overall, the exhibition emphasises the Jewish perspective of life in the transit camp to communicate a universal empathetic story - "it could have been you" - through the use of family photos (cf. BRINK 2000) and personal items. Little is depicted about the women, Sinti and Roma, and others interred here from 1942-45, or even stories about non-Jewish Dutch people (the majority of the population) living near the camp. ${ }^{6}$

In general, the Dutch people are depicted in the exhibition in neutral terms, largely as innocent bystanders, or not at all. Unlike the Westerbork Memorial Museum's webpage, there are a few stories from the perspectives of those who: "resisted the persecution of the Jews, who guarded the camp, who drove the deportation trains, and who lived near Westerbork" (KAMPWESTERBORK). If questions are raised about Dutch responsibility, these are made at the personal level; even the "Internment Camp Westerbork 1945-1948" online exhibition, discusses the Dutch National Socialist Movement (NSB), founded in 1931, in terms of "the hatred of 'bad' Dutch people" (Kampwesterbork). No exhibition systematically examines the collaborations of the Dutch government or society with the National Socialist regime. According to JANSEN (2015): "In comparison to other countries, a relatively large number of Jews from the Netherlands were murdered, which is due to various factors including the many officials cooperating with the Germans, the high concentration of Jews in Amsterdam, the cooperation of the Jewish Council, and the fact that the resistance, which has done much good, started relatively late in the Netherlands" (203).

\footnotetext{
6) The museum's webpage does a better job of providing a more inclusive history of those persecuted during WWII, even as it emphasizes a narrative of Jewish persecution. For example, a colour image of four multicultural young girls point to and look at a historic postcard in a glass vitrine of an exhibition at the "Camp Westerbork Museum" page (http:// kampwesterbork.nl/en/museum/herinneringscentrum/ camp-westerbork-museum/index.html). (This may be part of the museum's effort to draw attention to the fact that Anne Frank was interred here.) In scrolling images under 'Film Material' on the same page, a well-known black and white Holocaust image flashes: the young Sinti girl wearing a scarf, Settela Steinbach, who looks out a deportation train wagon. Steinbach stayed at some point in Westerbork.
}

The exhibition raises the question of what kind of violence is "valued" to elicit sympathy among visitors and what social discourses are used to "fit" this selective narrative of violence (cf. TYNER et al. 2014). In Westerbork, we have argued that the universal paradigm of Holocaust remembrance, with an emphasis on the Nazi perpetrated mass-killings of Jews, and of personal tragic stories such as Anne Frank, seems to overcome all the other forms of structural violence that has created this particular memoryscape (VAN DER LAARSE 2010). Such a representation, moreover, locates the memorial museum in limited spatial-temporal relationship to other places, in particular only to the violent landscapes of the Holocaust. It severely limits the possibilities of hearing a range of stories about this particular place.

\subsection{The memorial grounds: emptiness and glob- al Holocaust memory}

In the heritage business, the question of the authenticity of a site and its material environment is often raised (DeLyser 1999). Do Holocaust remembrance sites have to have "original" features and artefacts in order to be convincing? Many Holocaust memorial sites include large open areas where the barracks once stood, such as at Auschwitz-Birkenau and Dachau, but most also include real or recreated remnants, such as gates, train tracks, observation and shooting towers, crematoria, as well as memorials. At Westerbork, there are few material or recreated artefacts. After walking through a very open fencing system (one swings and latches the fence rather than walking under an entrance gate with a Nazi epitaph above), one walks into a large open field. Thus, part of the feeling of the authenticity of the Westerbork Camp Memorial area is its isolation and silence, an experience of a remote, not heavily signed and not clearly recognizable expansive open-air area that lends itself to the imagination. However, upon closer analysis, the present-day heritage site not only is a radically different environment than existed until 1971; during the war, transit camp inmates also transformed the natural environment by planting trees on the surrounding marshland during 1942-44 (Photo 2). This means that what seems today to be a largely 'natural' environment is actually an important part of the camp's (unsigned) history and claims to authenticity in present-day commemorative landscape.

A visit to the historic memorial terrain nonetheless offers a quite jarring contemporary experience: fourteen monumental radio telescopes, each 


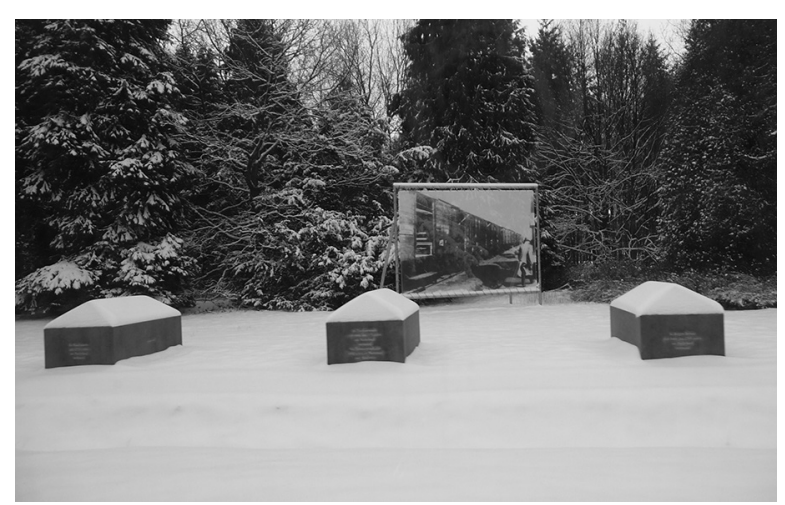

Photo 2: Forest around contemporary Westerbork heritage site (Photo: KuUsisto-ArPonen January 2013)

25 meters in height, stand on the right side of the memorial ground (Photo 3). Westerbork remains a unique "hot spot" in astronomy and space research due to the remoteness of the location. The distance from traffic and other airwave signals was one of the main reasons why the telescopes were erected at this location, in addition to the availability of large area of "empty" land. The presence of these monumental telescopes shifts one's more inward and attentive focus on learning about the history of the transit camp back to the present-day. We are reminded of the ways the past and present always co-exist in one location, even if these are not formally 'signed' in the landscape.

For memorial sites with multiple camp histories, including reuse after extreme moments of violence, decisions have to be made about what aspects of that past to represent in the landscape, where, in what form and in whose name. At Sachsenhausen, for example, following German reunification, memorial museum directors chose a "decentralized" approach on the historic grounds of the former camp to represent the history of the Nazi camp and its reuse as a postwar internment camp, as well as depict aspects of German Democratic Republic selective commemorative practices (1950-1989), while still maintaining an overall emphasis on the suffering of those who died and were imprisoned during World War II (TiLl 2005). In contrast, at Westerbork there is very little on the historical grounds that gives a sense of the camp's multi-layered history beyond its former function as a refugee and transit camp; the history of the internment camp, the period when Moluccan residents lived there, and finally debates about commemoration, including when the last remaining barracks destroyed or removed for reuse on farms nearby in 1970-71, are not presented.
The first phases of memorial "symbolic accretion" (DwYer 2006) began in 1970 and 1971, a rather late time compared to other memorial sites, such as in West and East Germany. Similar to Germany, this first phase of memorialization was initiated and demanded by survivors' groups, who dramatically changed the material landscapes (as did their relatives before them), for example, by removing all signs of post-war occupation. The two first artistic monuments of remembrance for those transported and killed during WWII stand towards the end of the larger memorial terrain, amidst largely open fields. The original monument designed by Ralph Prins, a former prisoner in this camp, is of a railroad line that has 93 tracks (representing the number of trains leaving the camp) ending in a circle so the train never again goes on the route. Above this circle, twisted and damaged rails lift upwards to the sky and are said to represent despair. Photographs of this memorial are still used as an icon for the camp, as are those of a watch-tower and some fencing that is visible from this location. The second, not-so-visible "Resistance Memorial" is marked by a gravestone behind the historic location of the camp's crematorium. The crematorium was commissioned by camp commander Gemmeker and came into use in 1943; ash and remains of resistance fighters and Jews cremated here were found in 1949. At the request of relatives, a gravestone with the names of known individuals was established by the survivors' “1940-1945 Foundation.” Although survivors wanted to preserve the crematorium, it was demolished in 1951 (KAMPWESTERBORK).

More recent memorials include "102,000," an installation of brick-colored stones topped mostly by Stars of David; about 200 have flames to represent Sinti and Roma, and 100 have no symbol to represent resistance fighters. Because there are no remains or final resting place for survivors and their families, "the

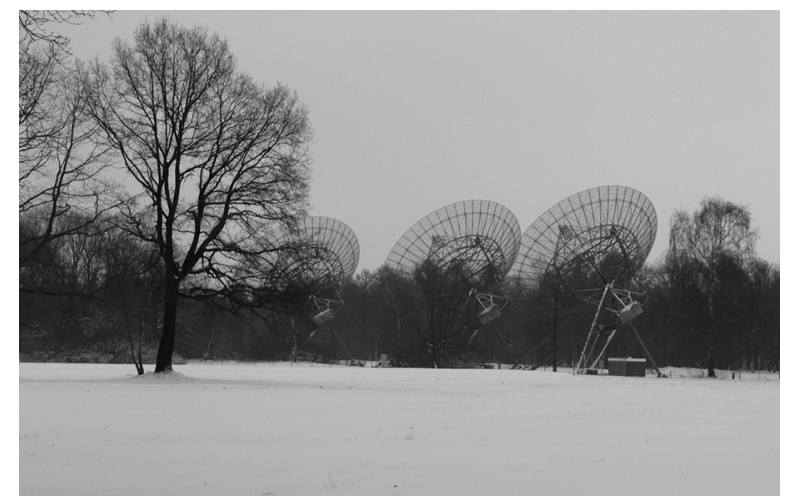

Photo 3: Empty space at camp heritage site with radio telescopes. (Photo: KuUsisto-ArPonen January 2013) 
stones are placed in such a way to emphasize individual people: 102.000 times a mother, a father, a son, a daughter, a brother, a sister ...." (KAMPWESTERBORK). It is located on the former parade ground of the camp, and resulted from the initiative of former prisoners with a goal of depicting how many people died here, suggesting that this was not evident or visible enough in either the museum's exhibition or the Dutch and international public's knowledge. The stones rise to different heights (to depict children and adults), but all just over ankle-height at the most; some are interspersed with small pictures of former inmates standing side by side on wires placed in the ground. The visitor has to look down or stoop down toward the ground to get closer views. However, from above, the stones are grouped together to form a geo-body of the Netherlands (Photo 4). Although the people who were sent to death from this camp came from many places, they are identified in three categories only; taken together, they form a national map - an image of Dutch suffering that is, in this historical place, problematic. Since 2001 the archival project has traced the names of the 102,000 people and for years these names have been read by volunteers every January 27, on International Holocaust Remembrance Day (Herinneringszentrum Kamp Westerbork, 2015). Inside the Memorial Centre, the names are continuously projected onto one of the walls.

In addition, the "Jerusalem Stone" was given as a gift in 1993 from Israeli President Chaim Herzog, in the presence of Dutch Queen Beatrix "in memory of the victims of Nazi terror and Westerbork"; "similar stones were also placed in Auschwitz and Bergen Belsen" (KAMPWESTERBORK). In 2001, a series of commemorative plaques designed by Victor Levie were unveiled near the entrance to the former camp by Jules Schelvis, one of eighteen Dutch survivors of the Sobibor, and former Prime Minister Wim Kok. Each plaque lists the destinations of extermination camps Westerbork inmates were sent to - Sobibor, Mauthausen, Bergen-Belsen, Auschwitz and Theresienstadt - as well as shows the numbers of deportees and victims (ibid). Other subtle signs and well-known Holocaust symbols are to be found in Camp Westerbork, perhaps to convince the visitor that real people with their families were once here before being transported to their death. A series of much less than life-size concrete barrack markers are located on the historic sites, mostly covered with mounds of snow in winter (Photo 2). Along the pathway, glass plaques are irregularly scattered throughout the empty camp scenery with (we assume reproductions of original) letters and

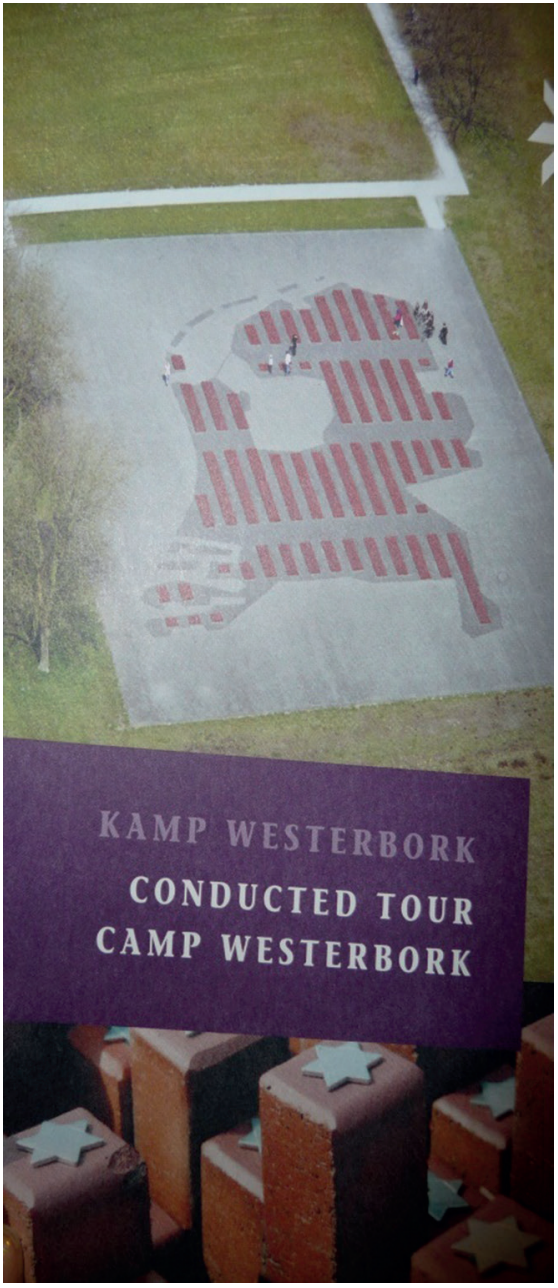

Photo 4: Cover page of the Westerbork brochure picturing the open-air monument at the camp-site. Red brick tiles are in the form of barracks and the entire constellation depicts the Netherlands map: national territory

postcards that were sent out from the camp by the inmates; selected words are printed in white. One can always look through these glass steles to see the wider landscapes (Photo 5).

Taken together, the remembrance symbols, memorials and empty fields claim our attention visually and mentally: We are asked not to forget. We were all part of this history. We are again asked to empathize with the suffering of the people who lived in and left the Westerbork transit camp. This kind of eye-witnessing paradigm is often used in heritage tourism and especially for Holocaust remembrance sites to evoke global and historical empathy (SundHolm 2011). Yet as we have suggested here, sometimes this universal historical empathy may result in other stories remaining untold and unheard (Moduln et al. 2011, 9). 


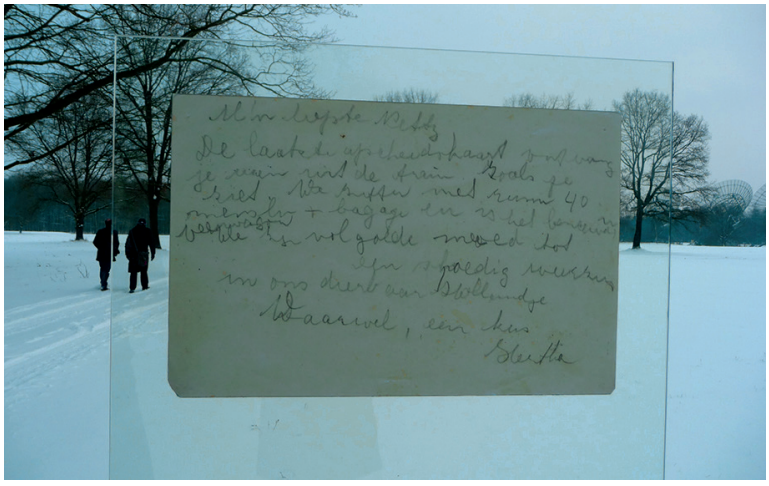

Photo 5: Letters from the past in the contemporary mnemonic landscape of Westerbork (Photo: KuUsisto-ARPONEN, January 2013).

\section{A changing landscape?}

When we asked about the emptiness of the memorial terrain, we learned in a tour from memorial staff members that survivors' groups strongly opposed any historic recreations of barracks on the historical terrain. Survivor groups at the time were clearly opposed to any strategies that would deter from their understanding of an appropriate open landscape of commemoration. In telling us this, some staff members expressed both a sense of responsibility toward respecting the rights of survivor groups to determine the material presence of this landscape, perhaps because this may have not been the case in the past, as well as frustration in not being able to use more recent approaches to Holocaust education and pedagogy in museums.

Upon reflection, the pedagogical challenge of physical emptiness is understandable when considering how the stories of survivors and their families had been silenced for decades following the end of WWII. However, the request by survivors and their families to leave the barracks fields empty and use only subtle, low-lying forms of commemoration, is now being revisited as a result of unexpected changes to the material landscape of Westerbork. In 2013, near the entrance to the historic memorial site, a large green house in very poor condition was surrounded by fencing and signs indicating a preservation project. This was the former Camp Commandant's house, which has since become part of the Memorial Museum Camp Westerbork's property (Photo 6). Until quite recently, relatives of those stationed here in the 1950s during the Dutch military camp years could make a legal claim to live here. The last person who could make that claim was an elderly woman, who had recently passed away when we visited. The addition of this historic, yet new, building to the otherwise empty memorial terrain resulted in conflicts between visions of the future landscape by memorial staff and survivors' groups.

On the one hand, some staff members seemed to be excited about this new acquisition. They discussed the possibilities of conserving the building as a shell, as very little of the interior furniture, wallpapering or other material aspects remained in original form; more extensive conservation plans, such as covering the entire house with glass, and providing an exhibition outside the house with historic pictures of the building during the transit camp phase were also described. In December 2014, this plan was realized, and the last panels of 12 meter-high glass roofing were placed over the house of the commander of Camp Westerbork. Oving Architects' innovative glass construction protects the house and creates a 'stage setting' that can 'welcome 100 persons' (Herinneringszentrum Kamp Westerbork, 2015).7) During our tour, some memorial staff also speculated about the possibilities of updating the terrain to include new research and an exhibition about perpetrator's histories. They felt that such an outdoor exhibition and the presence of an actual historic building would give the memorial terrain a level of authenticity not currently available in either the museum or the current terrain.

On the other hand, some memorial staff members noted that the relatives of the victims had strongly opposed these conservation and exhibition ideas, as they felt the physical presence of such a structure would materially privilege the perpetrator on this historic site of suffering. Having said this, they also noted that for visitors (especially younger visitors), it is difficult to imagine past conditions due to the empty terrain. We believe for this reason, in the museum exhibition, the 2009 installation of the remnant of Barrack 57 (where Anne Frank and her sister Margo worked), the partially recreated interior of a barrack, and the overall physical architecture of the exhibition provide a dramatic physical presence for at least some visitors.

Responses are mixed regarding the dramatic new architectural shell covering the commander's house. As one visitor commented: "I find it bitter

7) Hitting the 'Film Links' box on the Camp Museum Westerbork's webpage brings one to a youtube clip of the building of the Netherlands largest museum vitrine, which is accompanied by dramatic music (https://www.youtube.com/ user/Herinneringscentrum) 


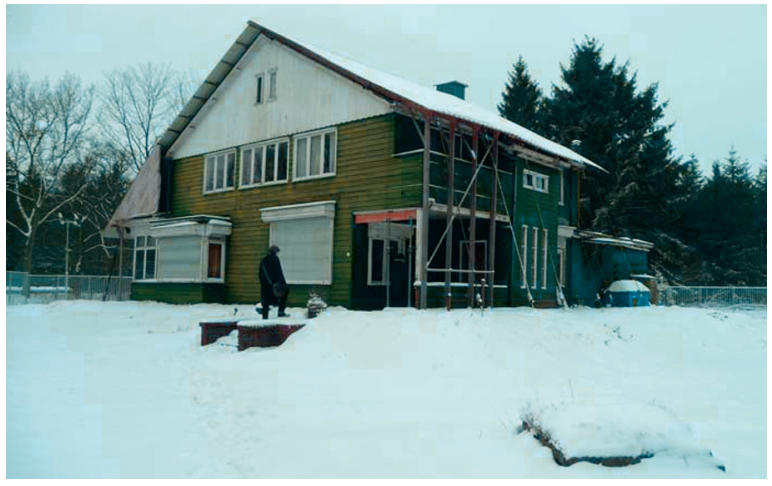

Photo 6: The old Commandant's house in camp Westerbork (Photo: KuUsisto-ArPonen January 2013)

that the wooden villa of the camp commander has remained standing, whereas a fire in Veendam in 2009 destroyed the barracks in which Anne dismantled batteries. 'It is a cruel twist of history that the residence of the camp commander still stands', the website of the Westerbork Camp states. It is, however, not history but human actions and failures that are responsible for this" (JANSEN 2015, 201). A form of commemorative competition has also emerged on the terrain. As if to reclaim the significance of the voices of those who suffered during the war, on the occasion of the $70^{\text {th }}$ anniversary of Westerbork's liberation, a new "speaking memorial", Voice Names, was launched in Spring 2015 (Dutch Online News 2015; RTV Drenthe 2015). This sound installation includes the names of former prisoners (Jews, Sinti and Roma, and resistance fighters) and selections from the diary of camp-prisoner Philip Mechanicus within two restored original train cars that regularly departed Westerbork to go to extermination camps during 1942-1944. Located on a piece of rail on "The Rampe" this sound sonic memorial adds a new aesthetic element to the original memorial complex that claims its authenticity through artefact, historic location, and Holocaust memorial iconography.

\section{Conclusion: towards responsible geogra- phies of memory}

That the 2011 IGU meeting in Santiago raised questions about the meanings of a place marked by traumatic national pasts, as well as larger unresolved issues about Geography's role in confronting questions national histories of violence, should not have been surprising as similar controversies have appeared during recent years (ALDERMAN and CAMPBELL
$2008)^{8)}$. Indeed at both the Instituto Geográfico Militar and Westerbork, geographers would question naïve interpretations of places and landscapes as "impartial recorders of history" or as communicating "seemingly authentic and unproblematic representations of histories" (Dwyer and Alderman 2008, $167,168)$. For this reason, we are also critical about claims made to the authenticity of places through singular narratives about the past. As we have argued in this article, the focus on a singular narratives of suffering, or stories about places that bracket the past so as not appear continuous with the present, may unintentionally silence stories rather than offer opportunities for visitors to engage in trying to understand the complexities of a place. Creating more inclusive places of memory requires critical reflections upon the concepts of violence, and the uneven dynamics of historical empathy through story-telling (see e.g. Moduin et al. 2011).

By way of conclusion, we outline how a placebased ethics of care (compare Till 2012) should be a central feature in the creation of responsible geographies of memory. First, we must respect the fact that landscapes often function as places of critical testimony for survivors, in the form of an expression of a societal "crisis of witnessing" during and after the times that violence happened (CARUTH 1995; FELMAN and Laub 1992). Those who have experienced physical and emotional violence may be unable or do not wish to articulate their experiences through narrative forms, and for this reason places and landscapes may provide an important non-linguistic presence (in memory, imagination, emotionally and/or materially) that will exist beyond the lifespan of the survivor (Till 2008). Public respect for the existence of these places also acknowledges the sense of responsibility survivors feel to those who did not survive (which is often tied to feelings of guilt for surviving) and survivors' need to testify following extremely violent periods, such as war, mass-murder and/or genocide. We must also remember that symbolic and structural forms of violence often follow extreme

\footnotetext{
8) Alderman and CAmpBell (2008) discuss the controversial 2007 meeting of the Southeastern Division of the Association of American Geographers in Charleston. In 2009 and 2010, geographers and international organisations petitioned the IGU to relocate the 2010 conference in Tel Aviv; the IGU executive committee rejected the request (https:/electronicintifada.net/ content/boycott-international-geographical-unions-regionalconference-tel-aviv/1071). Many subsequently boycotted the conference. In 2014, some geographers boycotted the AAG annual meeting in Tampa, FL due to injustices in Travon Martin's case and "Florida's stand-your-ground" law.
} 
periods of physical violence and injustice. This is certainly the case in Santiago at the Escuela Militar and in Westerbork for different reasons. When a society begins the processes of rebuilding, starting anew, or reconciling difficult pasts through truth commissions, sometimes survivors and their families (and communities) have little time to grieve and mourn.

Within the context of social and official forgetting, telling inclusive stories at places of past violence, especially in the case of Holocaust remembrance, is challenging. Those who experienced violence (including those who are no longer alive) may yet again be silenced, even when this is unintentional, and again experience new forms of violence and exclusion. This may take the form of official forgetful histories; renamed streets and new memorials; the razing and/or reuse of rubble, buildings, fields, and memorial sites; and the processes associated with state legal institutions and proceedings. In these social spaces, victims may experience a second erasure and societal distancing, especially when their injuries and stories are not given a shared space for storytelling (FELMAN 2002). When survivors return to a place, whether in the imagination or in person, that journey and being in a place offers individuals a possibility to step outside of existing social-spatial forms of silencing and instead create also a space-time for the possibilities for grieving, mourning, and remembering, as well as imagining different futures.

Second, to enable these emotional journeys heritage sites should not be based on the idea of a singular understanding of authenticity; nor should they depict exclusive historical narratives of place. By acknowledging the significance of place for the memory-work of survivors and their families, we also acknowledge the importance of that work for our society as a whole. Scholars, educators, museum designers, and pedagogues should be aware of and call attention to the problems of singular claims to authenticity as normalized through the landscape that may, even unintentionally, silence voices. Memorial sites need not be "authentic" for disagreements about interpretation and memorialization to emerge. These controversies are rarely localized or even national, but include geopolitical and transcultural concerns, including survivors' groups wishes, the needs of historical research, and the reality of dark tourism, including what the visitors' bring with them to their experience. In the case of Westerbork, the normative power of universal Holocaust narratives and the materiality of the landscape legitimate singular claims that have silenced other important stories that might offer the possibilities for critical reflection. Further, even though this is a rather provocative claim, we suggest that Westerbork as a heritage site is a place of unevenly developed historical empathy, that focuses on Holocaust violence and disregards other structural forms of violence tied to different understandings of national histories. We argue that instead of focusing on the coherence of narratives and the use of places, locations and material landscapes as "proof" of authenticity, heritage sites should utilise embodied experiences and learn to tell contradictory, rather than coherent, stories. A placebased approach to memory would offer guests a consideration of the spatial and temporal complexities of everyday practices, and transgenerational and translocational forms of belonging (KORJONEN-KuUSIPURO and Kuusisto-Arponen 2012; KuUsisto-Arponen 2015). Such an approach is needed at both the Escuela Militar and Westerbork.

Third, as citizens of the world, and as professional geographers, we have an ethical responsibility to try to understand why different social groups and individuals may wish to raise questions or stories about traumatic pasts at a particular place and moment in time, even if this means taking additional time to listen. Creating safe spaces for listening and learning should be a central educational goal of any memorial museum or when controversies emerge in places marked by violent heritage. At the 2011 IGU meetings this was a missed opportunity. As geographers, it was our responsibility to listen to the stories of those who suffered because these emerged as a result of our professional reuse of buildings or landscapes for the conferences. Not to acknowledge this is to support directly or indirectly past structures of state violence through our professional organizations and our research. Our status as international guests and visitors, and as scholars, and our presence in a place, may aid in the legitimizing claims of normalization that silence and repress the voices about place to whom we should be most attentive. Instead, symposia could have been organized in other venues whereby conference delegates could listen to, and possibly present contested histories. Publications, artistic installations, and/or films and exhibitions through visualizations of multilayered pasts could also be explored as spaces of discussion and listening. We are certainly not arguing that all voices have the same moral claims, but rather stressing the importance of paying attention to the complex space-times of places, as well as how our silences may contribute to existing problems of normalization through our international professional status. When considering forms of belonging within the contexts of traumatic national pasts, a range of registers may be needed. 
This leads us to our last point: we need to recognize the progressive potential of places as cosmopolitan spaces where critical encounters of memory politics should be nurtured. This requires actual work of memory activists (who often are also scholars) to create these cosmopolitan places of exchange and storytelling rather than just passively interpreting them or at its worst ignoring them with inaction and silence. DerRIDA (1994) argues that respect for justice means to consider both the pathways from whence we came as well as the "where" we are going toward in the future. He states, "without this responsibility and this respect for justice concerning those who are not there, of those who are no longer or who are not present and living, what sense would there to be ask the question 'where?' 'where tomorrow?' 'whither?"' (emphasis in original, ibid. xvii). Justice for DERRIDA means to consider all peoples, including those who have gone before and those yet to be born. Justice must mean the same thing for "my life" and "our life" tomorrow, that is for the life of others, as it was yesterday for others: beyond therefore the living present in general (ibid. xix).

As we have suggested in this article, attending to places marked by violence may help us relocate our focus from "my life" in the present to the space-times of the lives of others. Here, we might adopt ENTRIKIN's (1999) discussion of considering places once marked by violence as offering the possibilities of cosmopolitan spaces of encounter and learning. ENTRIKIN defines cosmopolitan place as self-consciously promoting progressive political agendas, such as participatory democracy and toleration, by simultaneously providing concrete relations that link individuals and groups to both a particular social milieu, as well as a universalized "here-ness." This here-ness centers on a "me" and "us," a potentially inclusive humanity (to include all life forms) that encourages the "opening up to view of the home, the workplace, the school and the onthe-ground activity of the local or national state" (ibid. 279). ENTRIKIN's description of the self-reflexive creation of "overlapping, differentiated places of attachment that have relatively permeable boundaries" (ibid.) is also echoed in the interdisciplinary literature on critical memory practices. Metaphors such as "giving voice," making absent presences visible, or uncovering forgotten pasts are strategies used to create more inclusive spaces.

When we acknowledge the progressive potential of places marked by violence as cosmopolitan spaces of encounter and learning, we can try to create safe spaces of listening to nurture this "here-ness", wherein stories about place by various stakeholders can be communicated while at the same time the moral complexity and contradictory nature of claims to the past can be acknowledged. At and through places marked by difficult pasts, when hosts and visitors can begin to engage critically with the unfolding processes of memory politics, as cosmopolitan citizens we may begin to care for each other by caring for place, and in so doing, begin the important work of imagining more just futures (Till 2012). By facilitating respectful spaces of encounter, even when social groups may have radically different understandings of places and pasts, we may begin a process becoming responsible for justice in the name of those here and those no longer or not yet here.

\section{Acknowledgements}

The authors wish to thank and acknowledge The Netherlands Institute for Advanced Study in the Social Sciences and Humanities (NIAS), as part of the grant for the international Terrorscapes Research Network during 2012 and 2013, and the Department of Geography at Maynooth University that supported our research and collaborations. Anna-Kaisa Kuusisto-Arponen wishes to thank the Academy of Finland (projects SA 266161 and SA 272168). Thanks are also extended to Dieter Soyez and Dirk Wundram for their support, as well as the excellent suggestions made by a reviewer.

\section{References}

Adams, P.; Hoelscher, S. and Till, K. (2001): Place in context: rethinking humanist geographies. In: ADAMS, P.; Hoelscher. S. and Till, K. (eds.): Textures of place. Minneapolis, xiii-xxxiii.

Agnew, J. (1998): The impossible capital: monumental Rome under liberal and fascist regimes, 18701943. In: Geografiska Annaler B 80, 229-240. DOI: 10.1111/j.0435-3684.1998.00042.x

Alderman, D. (2002): Street names as memorial arenas: the reputational politics of commemorating Martin Luther King Jr. in a Georgia county. In: Historical Geography 30, 99-120.

Alderman, D. and Campbell, R. (2008): Symbolic excavation and the artifact politics of remembering slavery in the American South. Observations from Walterboro, South Carolina. In: Southeastern Geographer, 48 (3), 338-325. DOI: 10.1353/sgo.0.0029 
Alderman, D. and Inwood, J. (2013): Landscapes of memory and socially just futures. In: JoHnson, N.; SCHEIN, R. and Winders, J. (eds.): The Wiley-Blackwell companion to cultural geography. Oxford, 186-197. DOI: 10.1002/9781118384466.ch18

Atkinson, D. and Cosgrove, D. (1998): Urban rhetoric and embodied identities: city, nation, and empire at the Vittorio Emanuele II monument in Rome, 1870-1945. In: Annals of the Association of American Geographers 88, 28-49. DOI: $10.1111 / 1467-8306.00083$

Azaryahu, M. (1997): German reunification and the politics of street names: the case of East Berlin. In: Political Geography 16, 479-493. DOI: 10.1016/s09626298(96)00053-4

Bell, M. M. (1997): The ghosts of place. In: Theory and Society 26, 813-836. DOI: 10.1023/A:1006888230610

Bosco, F. (2006): The Madres de Plaza de Mayo and three decades of human rights' activism: embeddedness, emotions and social rights movements. In: Annals of the Association of American Geographers 96, 342365. DOI: $10.1111 /$ j.1467-8306.2006.00481.x

BRINK, C. (2000): Secular icons: looking at photographs from Nazi concentration camps. In: History \& Memory 12 (1), 135-150. DOI: 10.2979/HIS.2000.12.1.135

Caruth, C. (ed.) (1995): Trauma: explorations in memory. Baltimore.

Certeau, M. De; Giard, L. and Mayo, P. (1998): The practice of everyday life. Vol. 2: living and cooking. Minneapolis.

Charlesworth, A. (1994): Contesting places of memory: the case of Auschwitz. In: Environment and Planning, D: Society and Space 12, 579-593. DOI: 10.1068/ d120579

Cresswell, T. (2006): On the move. Mobility in the modern western world. London.

DeLyser, D. (1999): Authenticity on the ground: engaging the past in a California ghost town. In: Annals of the Association of American Geographers 89, 602-632. DOI: $10.1111 / 0004-5608.00164$

- (2005): Ramona memories: tourism and the shaping of southern California. Minneapolis.

Derrida, J. (1994): Specters of Marx: the state of the debt, the work of mourning and the new International. London.

- (1995): On the name. Stanford, CA.

Doolan, P. (2010): Camp Westerbork: The Netherland's forgotten concentration camp. History News Network webpage.

http://hnn.us/article/127190\#sthash.c8AtsDq3.dpuf (Accessed 30 March 2014)

Dwyer, O. (2006): Symbolic accretion and commemoration. In: Social and Cultural Geography 5, 419-435. DOI: $10.1080 / 1464936042000252804$
Dwyer, O. and Alderman, D. (2008): Memorial landscapes: analytic questions and metaphors. In: Geoforum 73, 165-178. DOI: 10.1007/s10708-008-9201-5

Dutch Online News. (2015): New 'speaking monument' Kamp Westerbork: http://dutchrecentnews.blogspot. ie/2015/04/new-speaking-monument-kamp-westerbork.html (Accessed 30.06.2015)

Entrikin, N. (1999): Political community, identity and cosmopolitan place. In: International Sociology 14, 269282. DOI: $10.1177 / 0268580999014003003$

ErLt, A. (2011): Travelling memory. In: Parallax 17, 4-18. DOI: $10.1080 / 13534645.2011 .605570$

FeLman, S. (2002): The juridical unconscious: trials and traumas in the twentieth century. Cambridge, MA.

Felman, S. and Laub, D. (1992): Testimony: crises of witnessing in literature, psychoanalysis, and history. London.

Foote, K. (1997): Shadowed grounds: America's landscapes of violence and tragedy. Austin.

Forest, B. and Johnson, J. (2002): Unraveling the threads of history: Soviet-era monuments and post-Soviet national identity in Moscow. In: Annals of the Association of Geographers 92, 524-547. DOI: 10.1111/14678306.00303

Forest, B.; Johnson, J. and Till, K. (2004): Post-totalitarian identity: public memory in Germany and Russia. In: Social and Cultural Geography 5, 357-380. DOI: $10.1080 / 1464936042000252778$

François, E. and Schulze, H. (eds.) (2001): Deutsche Erinnerungsorte. München.

- (eds.) (2005): Deutsche Erinnerungsorte. Eine Auswahl. München.

Halbwachs, M. (1950): La mémoire collective. Paris.

- (1992): On collective memory. Chicago and London.

Harvey, D. (1979): Monument and myth. In: Annals of the Association of American Geographers 69, 362-381. DOI: $10.1111 /$ j.1467-8306.1979.tb01262.x

HefFernan, M. (1995): For ever England: the western front and the politics of remembrance in Britain. In: Ecumene 2, 293-324. DOI: 10.1177/147447409500200304

Herinneringszentrum Kamp Westerbork (2015): Getekend Nieuws 1, 5. Available at: http://www.kampwesterbork. nl/contentfiles/Document/41/40816.pdf. (Accessed 30.06.2015).

Hetherington, K. (1997): In place of geometry: the materiality of place. In: Hetherington, $\mathrm{K}$. and Munro, R. (eds.) Ideas of difference. Oxford, 183-199.

Hill, L. (2013): Archaeologies and geographies of the post-industrial past: landscape, memory and the spectral. In: Cultural Geographies 20, 379-396. DOI: $10.1177 / 1474474013480121$

Hirsch, M. (2012): The generation of postmemory: writing and visual culture after the Holocaust. New York. 
Hirt, I. and Palomino-Schalsha, M. (2011): Geography, the military and political critique on the occasion of the 2011 IGU Regional Meeting in Santiago de Chile. In: Political Geography 30, 355-357. DOI: 10.1016/j. polgeo.2011.07.003

Hoelscher, S. (1998): Heritage on stage: the invention of ethnic place in America's Little Switzerland. Madison.

Hoelscher, S. and Alderman, D. (2004): Memory and place: geographies of a relationship. In: Social and Cultural Geography 5, 347-355. DOI: 10.1080/1464936042000252769

Jansen, R. W. (2015): Anne Frank. Silent witnesses: reminders of a Jewish girl's life. Berlin

Johnson, N. (1999): The spectacle of memory: Ireland's remembrance of the Great War, 1919. In: Journal of Historical Geography 25, 36-56. DOI: 10.1006/ jhge.1998.0106

Jonker, J. and Till, K. (2009): Mapping and excavating spectral traces in post-apartheid Cape Town. In: Memory Studies 2,1-31. DOI: 10.1177/1750698008337561

KAMPWESTERBORK (Herinneringszentrum Kamp Westerbork website): http://www.kampwesterbork.nl/en/. (Accessed 21.09.2015).

Korjonen-Kuusipuro, K. and Kuusisto-Arponen, A.-K. (2012): Emotional silences: the rituals of remembering the Finnish Karelia. In: Törnquist-Plewa, B. and Bernsand, N. (eds.): Painful pasts and useful memories. Remembering and forgetting in Europe. Centre for European studies, Lund, 109-126.

Kull, C. (2011): Protest and politics at the Santiago geography conference. December 1. Electronic blog post. Available at: http://christiankull.net/2011/12/01/ protest-and-politics-at-the-santiago-geography-conference/ (Accessed 23.07.2013).

Kuusisto, A.-K. (2001): Territoriality, symbolism and the challenge. In: Peace Review, 13 (1), 59-66. DOI: 10.1080/10402650120038152

Kuusisto-Arponen, A.-K. (2009): The mobilities of forced displacement commemorating Karelian evacuation in Finland. In: Social and Cultural Geography 10, 545-563. DOI: $10.1080 / 14649360902974464$

- (2011): The politics of identity and visuality: the case of Finnish war children. In: Sтосснетт, M. and KuKKONEN, K. (eds.): Images in use: towards the critical analysis of visual communication. Amsterdam, 181-198. DOI: $10.1075 /$ dapsac. $44.11 \mathrm{kuu}$

- (2014): Silence, childhood displacement and spatial belonging. In: ACME, An International E-Journal for Critical Geographies 13 (3), 434-441. http://www.acme-journal.org/vol13/KuusistoArponen2014.pdf

- (2015): Self, place and memory: spatial trauma among British and Finnish war children. In: Harker, C. and Horschelmann, K. (eds.): Geographies of children and young people: conflict, violence and peace. Vol. 11 of: Skelton, T. (series editor): Geographies of Children and Young People. Singapore.

Levy, D. and Sznaider, N. (2005): The Holocaust and memory in the global age. Philadelphia, PA.

Massey, D. (1991): A global sense of place. In: Marxism Today Magazine (June), 24-29.

- (2005): For space. London.

McDowell, S. (2009): Memory. In: Thrift, N. and Kitchin, R. (eds.): International encyclopedia of human geography Vol. 7. Elsevier Online, 59-63. DOI: 10.1016/b978008044910-4.00388-6

Modlin, E.; Alderman, D. and Gentry, G. (2011): Tour guides as creators of empathy: the role of affective inequality in marginalising the enslaved at plantation house museums. In: Tourist Studies, 11 (1), 3-19. DOI: 10.1177/1468797611412007

Nora, P. (1984): Les Lieux de Mémoire. Vol. 1: La République. Paris.

Nora, P. and Kritzman, L. (eds.) (1996): Realms of memory: The construction of the French Past. Vol. 3. New York.

Pile, S. (2005): Real cities: modernity, space and the phantasmagorias of city life. London. DOI: 10.4135/9781446220665

RTV Drenthe. (2015): Nieuw 'sprekend monument' voor Kamp Westerbork. http://www.rtvdrenthe.nl/nieuws/ nieuw-sprekend-monument-voor-kamp-westerbork (Accessed 30.06.2015)

SANGER, N. (2012): Notes from the 2011 International Geographical Union conference in Santiago, Chile.' November 3. Slide presentation available at: http://www. slideshare.net/noashx/notes-from-the-2011-international-geographical-union-conference-in-santiago-chile. (Accessed 23.07.2013)

Sundholm, J. (2011): Visions of transnational memory. In: Journal of Aesthetic and Culture 3. DOI: 10.3402/jac. v3i0.7208

TiLL, K. E. (1999): Staging the past: landscape designs, cultural identity, and Erinnerungspolitik at Berlin's Neue Wache. In: Ecumene 6 (3), 251-283. DOI: 10.1191/096746099701556277

- (2003): Places of memory. In: Agnew, J.; Мiтchell, K. and O' Tuathail, G. (eds.): A companion to political geography. Oxford, 289-301. DOI: 10.1002/9780470998946.ch19

- (2005): The new Berlin: memory, politics, place. Minneapolis. - (2008): Artistic and activist memory-work: approaching place-based practice. In: Memory Studies 1, 95-109. DOI: $10.1177 / 1750698007083893$

- (2012): Wounded cities: memory-work and a place-based ethics of care. In: Political Geography 31, 3-14. DOI: 10.1016/j.polgeo.2011.10.008 
Tyner, J.; Inwood, J. and Alderman, D. (2014): Theorizing violence and the dialectics of landscape memorialisation: a case study of Greensboro, North Carolina. In: Environment and Planning D: Society and Space 32, 902-914. DOI: 10.1068/d13086p

van der LaArse, R. (2010): De Oorlog als beleving. Over de musealisering en enscenering van Holocaust-erfgoed. Instituut voor Cultuur en Geschiedenis (ICG). http:// dare.uva.nl/document/2/93516

Velasco, A. (2013): June 16. Response to Christian Kull's blog post. Available at: http://christiankull. net/2011/12/01/protest-and-politics-at-the-santiagogeography-conference/ (Accessed 23.07.2013)

Withers, C. W. (1996): Place, memory, monument: memorializing the past in contemporary highland Scotland. In: Ecumene 3, 325-344. DOI: $10.1177 / 147447409600300304$

\section{Authors}

Dr Karen E. Till Maynooth University Department of Geography Maynooth, County Kildare Ireland karen.till@nuim.ie

Dr Anna-Kaisa Kuusisto-Arponen University of Tampere School of Management (JKK) SPARG and RELATE research groups FI-33014 Tampere Finland anna-kaisa.kuusisto@uta.fi 